\title{
Impacts of climate variability and extremes on global net primary production in the first decade of the 21 st century
}

\author{
PAN Shufen ${ }^{1,2}$, TIAN Hanqin ${ }^{1}$, DANGAL Shree R.S. ${ }^{1}$, OUYANG Zhiyun ${ }^{2}$, \\ LU Chaoqun ${ }^{1}$, YANG $\mathrm{Jia}^{1}$, TAO Bo ${ }^{1}$, REN Wei ${ }^{1}$, BANGER Kamaljit ${ }^{1}$, \\ YANG Qichun ${ }^{1}$, ZHANG Bowen ${ }^{1}$
}

1. International Center for Climate and Global Change Research, School of Forestry and Wildlife Sciences, Auburn University, AL-36849, USA;

2. State Key Laboratory of Urban and Regional Ecology, Research Center for Eco-Environmental Sciences, CAS, Beijing 100085, China

\begin{abstract}
A wide variety of studies have estimated the magnitude of global terrestrial net primary production (NPP), but its variations, both spatially and temporally, still remain uncertain. By using an improved process-based terrestrial ecosystem model (DLEM, Dynamic Land Ecosystem Model), we provide an estimate of global terrestrial NPP induced by multiple environmental factors and examine the response of terrestrial NPP to climate variability at biome and global levels and along latitudes throughout the first decade of the 21 st century. The model simulation estimates an average global terrestrial NPP of $54.6 \mathrm{Pg} \mathrm{C} \mathrm{yr}^{-1}$ during 2000-2009, varying from 52.8 $\mathrm{Pg} \mathrm{C} \mathrm{yr}^{-1}$ in the dry year of 2002 to $56.4 \mathrm{Pg} \mathrm{C} \mathrm{yr}^{-1}$ in the wet year of 2008. In wet years, a large increase in terrestrial NPP compared to the decadal mean was prevalent in Amazonia, Africa and Australia. In dry years, however, we found a 3.2\% reduction in global terrestrial NPP compared to the decadal mean, primarily due to limited moisture supply in tropical regions. At a global level, precipitation explained approximately $63 \%$ of the variation in terrestrial NPP, while the rest was attributed to changes in temperature and other environmental factors. Precipitation was the major factor determining inter-annual variation in terrestrial NPP in low-latitude regions. However, in mid- and high-latitude regions, temperature variability largely controlled the magnitude of terrestrial NPP. Our results imply that projected climate warming and increasing climate extreme events would alter the magnitude and spatiotemporal patterns of global terrestrial NPP.
\end{abstract}

Keywords: climate variability; climate extreme; drought; global terrestrial ecosystem; net primary production (NPP)

Received: 2014-05-29 Accepted: 2014-11-29

Foundation: NSF Decadal and Regional Climate Prediction using Earth System Models, No.AGS-1243220; NSF Dynamics of Coupled Natural and Human Systems, No.1210360; NSF Computer and Network Systems, No.CNS-1059376; NASA Land Cover/Land Use Change Program, No.NNX08AL73G S01; NASA Interdisciplinary Science Program, No.NNX10AU06G, No.NNX11AD47G

Author: Pan Shufen, PhD, E-mail: panshuf@auburn.edu 


\section{Introduction}

Terrestrial plants convert atmospheric carbon dioxide $\left(\mathrm{CO}_{2}\right)$, water, and nutrients into organic carbon compounds through photosynthesis, a process known as gross primary production (GPP). A significant fraction of GPP is used for plant growth and maintenance while the remainder is net primary production (NPP), calculated as the difference between GPP and autotrophic respiration. NPP is important for maintaining ecosystem integrity and sustaining human society by providing food, fiber, and wood (Costanza et al., 1998; Running et al., 2004). Terrestrial NPP is also an essential component of the global carbon cycle (Melillo et al., 1993) that links terrestrial biota with the atmosphere (Beer et al., 2010). Monitoring and modeling GPP and NPP at regional and global scales have attracted much attention (Pan et al., 2014b; Running et al., 2004; Tian et al., 1998) because they not only measure the transfer of energy to the biosphere and terrestrial $\mathrm{CO}_{2}$ assimilation, but also because they provide the basis for assessing the status of a wide range of ecological processes (Piacentini and Rosina, 2012).

Due to the high heterogeneity of land surface, spatio-temporal patterns of GPP and NPP vary substantially among different vegetation types and across different regions. Investigating factors controlling changes in terrestrial primary production could provide important clues to the underlying mechanisms and advance our understanding of the complex interactions among terrestrial ecosystems, atmosphere, and climate system (Tian et al., 2000). During the past decades, GPP and NPP estimation and investigation of their influencing factors, especially at large scales, have drawn much attention among the scientific community, policy-making agencies, and the public due to global climate change and increases in the atmospheric $\mathrm{CO}_{2}$ concentration (Zscheischler et al., 2014; Pan et al., 2014b; Sitch et al., 2008). Since the global GPP is roughly $120 \mathrm{Pg} \mathrm{C} \mathrm{yr}^{-1}$ and is the largest flux of the global carbon cycle (Beer et al., 2010), even small fluctuations in GPP and NPP (usually estimated as half of GPP) could cause large changes in the airborne fraction of anthropogenic $\mathrm{CO}_{2}$ (Raupach et al., 2008). Thus the accuracy of estimating terrestrial primary production directly determines the magnitude and location of terrestrial net carbon fluxes (sinks and sources), which have been regarded as key ecological indices for evaluating terrestrial ecosystem dynamics and their feedback to the climate system in response to multi-factor global changes.

Using the remote sensing-based approach, several studies have concluded that climate change was the major driver of variation in terrestrial NPP over the previous three decades (Nemani et al., 2003; Potter et al., 2012; Zhao and Running, 2010). Nemani et al. (2003) found that climate change resulted in an increase in global terrestrial NPP by $6 \%$, with the largest increase in low-latitude ecosystems during 1982-1999. Over the recent decade (2000-2009), Zhao and Running (2010) estimated a global terrestrial NPP of 53.5 Pg C $\mathrm{yr}^{-1}$ using remote sensing algorithm, while Potter et al. (2012) estimated a global terrestrial NPP of 50.5 $\mathrm{Pg} \mathrm{C} \mathrm{yr}^{-1}$ using CASA model. Although their estimates (53.5 vs. $50.5 \mathrm{Pg} \mathrm{C} \mathrm{yr}^{-1}$ ) are comparable at the global level, they provide different mechanisms for variation in NPP across years. For example, Zhao and Running (2010) found that increased water stress and autotrophic respiration due to warming in the Southern Hemisphere was the major factor driving global terrestrial NPP, while Potter et al. (2012) found that warming temperature in 
high-latitude ecosystems was the major factor that controlled the magnitude of global terrestrial NPP during 2000-2009. While there is little doubt that climate change and increasing atmospheric $\mathrm{CO}_{2}$ are the primary drivers of terrestrial NPP during the recent decade, the mechanisms for this phenomenon are still far from clear and require further investigation.

Process-based ecosystem models are an effective tool for historical assessment and future projections of terrestrial NPP in response to global change (Chen et al., 2012; Huntzinger et al., 2012; Pan et al., 2014a; Pan et al., 2014b; Tian et al., 2000). These models integrate the understanding of complex ecological and physiological processes obtained from field measurements to study the response of terrestrial ecosystems to multiple environmental factors (Dermody, 2006; Norby and Luo, 2004; Wang et al., 2011). A number of process-based ecosystem models have been developed to estimate NPP response to changes in climate and increasing atmospheric $\mathrm{CO}_{2}$ at continental and global scales (Melillo et al., 1993; Ruimy et al., 1996; Sitch et al., 2003) for both contemporary and future climatic conditions. However, much uncertainty still exists about the key processes controlling ecosystem productivity and their responses to climate variability, including physiological processes, biogeochemical processes, and the impact of anthropogenic and natural disturbances (Cramer et al., 1999; Huntzinger et al., 2012). To improve the model's ability in predicting the impacts of climate change on terrestrial NPP in the future, it is essential to evaluate contemporary patterns of terrestrial NPP over time and space. The purpose of this study is to investigate the magnitude and spatio-temporal variations in terrestrial NPP during the first decade of the 21st century by using a process-based ecosystem model (the Dynamic Land Ecosystem Model, DLEM). The specific objectives are to: 1) evaluate the DLEM performance on the simulation of terrestrial NPP at both site and global levels, 2) provide an independent estimate of global NPP for the first decade of the 21st century, and 3) quantify inter-annual and spatial variations of terrestrial NPP in response to changes in temperature and precipitation.

\section{Methodology}

\subsection{Model description}

The DLEM is a highly integrated, process-based ecosystem model that simulates the structural and functional dynamics of terrestrial ecosystems affected by climate, atmospheric chemistry $\left(\mathrm{CO}_{2}\right.$ concentration, nitrogen deposition, and tropospheric ozone), land cover/land use change (LCLUC), and land management practices such as harvest, rotation, and fertilization. The DLEM simulates the linkage between carbon, nitrogen and water cycles across the plant-soil-atmosphere continuum as a function of five core components: 1) biophysics, 2) plant physiology, 3) soil biogeochemistry, 4) dynamic vegetation, and 5) land use and management (Tian et al., 2010a; Tian et al., 2010b). This model has been extensively calibrated across sites dominated by various plant functional types (PFTs), including forest, grassland, and cropland. The observational data used for model calibration are mainly from the Chinese Ecological Research Network, US Long Term Ecological Research (LTER) sites, and AmeriFlux network. After evaluating the model performance at the site level, DLEM has been widely used to simulate the effects of climate variability and change, atmospheric $\mathrm{CO}_{2}$, tropospheric $\mathrm{O}_{3}$, nitrogen deposition, and LCLUC on the pools and fluxes of carbon 
and water in China (Lu and Tian, 2013; Lu et al., 2012; Ren et al., 2007; Ren et al., 2011; Tian et al., 2011), the continental United States (Song et al., 2013; Tian et al., 2010a; Zhang et al., 2007; Zhang et al., 2012; Zhang et al., 2010) and North America (Tian et al., 2010c; Xu et al., 2010).

The uptake of atmospheric $\mathrm{CO}_{2}$ by terrestrial ecosystems through photosynthesis (GPP) is simulated based on the Farquhar model (Collatz et al., 1991; Farquhar et al., 1980). The NPP is estimated as a difference between GPP and autotrophic respiration. The model representation of underlying processes determining carbon assimilation and loss are described by Tian et al. (2010a). Recently, we updated the model to the DLEM 2.0 to include the dynamic linkages between terrestrial and riverine ecosystems (Liu et al., 2013; Tian et al., 2012). Here, we provide a brief description on how the DLEM simulates primary productivity (GPP and NPP) in the next section.

\subsection{Modeling gross primary productivity (GPP) in the DLEM}

In the DLEM, a modified Farquhar's model is used to simulate GPP (Bonan, 1996; Collatz et al., 1991; Farquhar et al., 1980). The canopy is divided into sunlit and shaded layers. GPP $\left(\mathrm{g} \mathrm{C} \mathrm{m}^{-2}\right.$ day $\left.^{-1}\right)$ is calculated by scaling leaf assimilation rates $\left(\mu \mathrm{mol} \mathrm{CO} \mathrm{CO}^{-2} \mathrm{~s}^{-1}\right)$ up to the whole canopy:

$$
\begin{gathered}
G P P_{\text {sun }}=12.01 \times 10^{-6} \times A_{\text {sun }} \times \text { plai }_{\text {sun }} \times \text { dayl } \times 3600 \\
G P P_{\text {shade }}=12.01 \times 10^{-6} \times A_{\text {shade }} \times \text { plai }_{\text {shade }} \times \text { dayl } \times 3600 \\
G P P=G P P_{\text {sun }}+G P P_{\text {shade }}
\end{gathered}
$$

where $G P P_{\text {sun }}$ and $G P P_{\text {shade }}$ are sunlit and shaded canopy, respectively; $A_{\text {sun }}$ and $A_{\text {shade }}$ are assimilation rates of sunlit and shaded canopy; plai $_{\text {sun }}$ and plai $_{\text {shade }}$ are the sunlit and shaded leaf area indices; dayl is daytime length (hour) in a day. $12.01 \times 10^{-6}$ is a constant to change the unit from $\mu \mathrm{mol} \mathrm{CO}_{2}$ to gram $\mathrm{C}$.

The plai $_{\text {sun }}$ and plai $_{\text {shade }}$ are estimated as:

$$
\begin{aligned}
& \text { plai }_{\text {sun }}=1-E X P\left(- \text { proj }_{\mathrm{LAI}}\right) \\
& \text { plai }_{\text {shade }}=\operatorname{proj}_{L A I}-\text { plai }_{\text {sun }}
\end{aligned}
$$

where $\operatorname{proj}_{L A I}$ is the projected leaf area index, which is calculated as the product of leaf carbon content $\left(\mathrm{g} \mathrm{C} \mathrm{m}^{-2}\right)$ and PFT Specific Leaf Area (SLA, $\left.\mathrm{m}^{2} \mathrm{~g} \mathrm{C}^{-1}\right)$. The major parameters in estimating photosynthesis are listed in Table 1. Using similar methods to Collatz et al. (1991), DLEM determines the $\mathrm{C}$ assimilation rate as the minimum of three limiting rates, $w_{c}$, $w_{j}, w_{e}$, which are functions that represent the assimilation rates as limited by the efficiency of the photosynthetic enzymes system (Rubisco-limited), the amount of Photosynthetically Active Radiation (PAR) captured by the leaf chlorophyll (light-limited), and the capacity of the leaf to export or utilize the products of photosynthesis (export-limited) for $\mathrm{C}_{3}$ species, respectively. For $\mathrm{C}_{4}$ species, $w_{e}$ refers to the PEP carboxylase limited rate of carboxylation. The canopy sunlit and shaded carbon assimilation rate can be estimated as:

$$
\begin{gathered}
A=\min \left[w_{c}, w_{j}, w_{e}\right] \times \text { Index }_{g s} \\
w_{c}=\left\{\begin{aligned}
\frac{\left(c_{i}-\Gamma_{*}\right) V_{\max }}{c_{i}+K_{c}\left(1+o_{i} / K_{o}\right)} & \text { for } C_{3} \text { plants } \\
V_{\max } & \text { for } C_{4} \text { plants }
\end{aligned}\right.
\end{gathered}
$$




$$
w_{j}=\left\{\begin{aligned}
\frac{\left(c_{i}-\Gamma_{*}\right) 4.6 \varphi \alpha}{c_{i}+2 \Gamma_{*}} & \text { for } C_{3} \text { plants } \\
4.6 \varphi \alpha & \text { for } C_{4} \text { plants }
\end{aligned}\right.
$$

Table 1 Major Parameters for net primary production (NPP) simulation in the Dynamic Land Ecosystem Model (DLEM)

\begin{tabular}{|c|c|c|c|c|c|c|c|c|}
\hline BIOME & $\mathrm{V}_{\max 25}$ & $\mathrm{CN}_{\text {leaf_min }}$ & $\begin{array}{c}\text { SLA } \\
\left(\mathrm{m}^{2} \mathrm{gC}^{-1}\right)\end{array}$ & $\begin{array}{c}\mathrm{r}_{\mathrm{b}} \\
\left(\mathrm{s} \mathrm{m}^{-1}\right)\end{array}$ & $\begin{array}{c}R_{\text {coeff leaf }} \\
\left(\mathrm{gC} \mathrm{gC}^{-1} \text { day }^{-1}\right)\end{array}$ & $\begin{array}{c}R_{\text {coeff_sapwood }} \\
\left(\mathrm{gC} \mathrm{gC}^{-1} \mathrm{day}^{-1}\right)\end{array}$ & 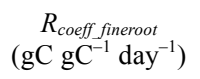 & $\begin{array}{c}R_{\text {coeff_coarseroot }} \\
\left(\mathrm{gC} \mathrm{gC}^{-1} \text { day }^{-1}\right)\end{array}$ \\
\hline Tundra & 50 & 30 & 0.04 & 25 & 0.003 & NA & 0.002 & NA \\
\hline BNEF & 55 & 30 & 0.02 & 11 & 0.003 & 0.0005 & 0.001 & 0.0005 \\
\hline BNDF & 60 & 30 & 0.05 & 11 & 0.003 & 0.0005 & 0.001 & 0.0005 \\
\hline TBDF & 50 & 30 & 0.06 & 100 & 0.003 & 0.0005 & 0.001 & 0.0005 \\
\hline TBEF & 70 & 30 & 0.035 & 100 & 0.003 & 0.0005 & 0.001 & 0.0005 \\
\hline TNEF & 60 & 30 & 0.02 & 11 & 0.003 & 0.0005 & 0.001 & 0.0005 \\
\hline TNDF & 55 & 30 & 0.05 & 11 & 0.003 & 0.0005 & 0.001 & 0.0005 \\
\hline TrBDF & 55 & 30 & 0.035 & 100 & 0.003 & 0.0005 & 0.001 & 0.0005 \\
\hline TrBEF & 70 & 30 & 0.035 & 100 & 0.003 & 0.0005 & 0.001 & 0.0005 \\
\hline Dec. Shrub & 45 & 30 & 0.025 & 50 & 0.003 & 0.001 & 0.002 & 0.001 \\
\hline Eve. Shrub & 50 & 30 & 0.025 & 50 & 0.003 & 0.001 & 0.002 & 0.001 \\
\hline C3 grass & 50 & 30 & 0.04 & 25 & 0.003 & NA & 0.002 & NA \\
\hline C4 grass & 24 & 30 & 0.04 & 25 & 0.003 & NA & 0.002 & NA \\
\hline
\end{tabular}

Note: BNEF, Boreal Needleleaf Evergreen Forest; BNDF, Boreal Needleleaf Deciduous Forest; TBDF, Temperate Broadleaf Deciduous Forest; TBEF, Temperate Broadleaf Evergreen Forest; TNEF, Temperate Needleleaf Evergreen Forest; TNDF, Temperate Needleleaf Deciduous Forest; TrBDF, Tropical Broadleaf Deciduous Forest; TrBEF, Tropical Broadleaf Evergreen Forest. NA, Not Applicable.

$$
w_{e}=\left\{\begin{aligned}
0.5 V_{\max } & \text { for } C_{3} \text { plants } \\
4000 V_{\max } \frac{c_{i}}{P_{\text {atm }}} & \text { for } C_{4} \text { plants }
\end{aligned}\right.
$$

where $c_{i}$ is the internal leaf $\mathrm{CO}_{2}$ concentration $(\mathrm{Pa}) ; o_{i}$ is the $\mathrm{O}_{2}$ concentration $(\mathrm{Pa}) ; \Gamma_{*}$ is the $\mathrm{CO}_{2}$ compensation point $(\mathrm{Pa}) ; K_{c}$ and $K_{o}$ are the Michaelis-Menten constants for $\mathrm{CO}_{2}$ and $\mathrm{O}_{2}$, respectively; $\alpha$ is the quantum efficiency; $\varnothing$ is the absorbed photosynthetically active radiation $\left(\mathrm{W} \cdot \mathrm{M}^{-2}\right) ; V_{\max }$ is the maximum rate of carboxylation varying with temperature, foliage nitrogen concentration, and soil moisture (Bonan, 1996):

$$
V_{\max }=V_{\max 25} a_{v \max } \frac{T_{\text {day }}-25}{10} f(N) f\left(T_{\text {day }}\right) \beta_{t}
$$

where $V_{\max 25}$ is the value at $25 \mathrm{C}$ and $a_{v \max }$ is a temperature sensitivity parameter; $f\left(T_{\text {day }}\right)$ is a function of temperature related metabolic processes (Collatz et al., 1991; Farquhar et al., 1980).

$$
f\left(T_{\text {day }}\right)=\left[1+\exp \left(\frac{-220000+710\left(T_{\text {day }}+273.16\right)}{8.314\left(T_{\text {day }}+273.16\right)}\right)\right]^{-1}
$$

$f(N)$ adjust the rate of photosynthesis for foliage nitrogen 


$$
f(N)=\min \left(\frac{N_{\text {leaf }}}{N_{\text {leaf_opt }}}, 1\right)
$$

where $N_{\text {leaf }}$ is the nitrogen concentration, $N_{\text {leaf_opt }}$ is the optimal leaf nitrogen concentration for photosynthesis, which is calculated based on leaf carbon content and the minimum leaf $\mathrm{CN}$ ratio $\left(C N_{\text {leaf_min }}\right)$.

$\beta_{t}$ is a function, ranging from one to zero which represents the soil moisture and lower temperature effects on stomatal resistance and photosynthesis

$$
\begin{aligned}
& \beta_{t}=\beta\left(T_{\text {min }}\right) \times \beta(w) \\
& \beta\left(T_{\min }\right)= \begin{cases}0 & \text { for } T_{\min }<-8^{\circ} \mathrm{C} \\
1+0.125 T_{\min } & \text { for }-8^{\circ} \mathrm{C} \leqslant T_{\min } \leqslant 0^{\circ} \mathrm{C} \\
1 & \text { for } T_{\min }>0^{\circ} \mathrm{C}\end{cases} \\
& \beta(w)=\sum_{i=1}^{2} w_{i} r_{i} \\
& w_{i}= \begin{cases}0 & \text { for } p s_{i}>p s i_{-} \text {close } \\
\frac{p s i_{-} \text {close }-p s_{i}}{p s i \_c l o s e-p s i \_o p e n} & \text { for } p s i_{-} \text {open } \leqslant p s_{i} \leqslant p s i_{-} \text {close } \\
1 & \text { for } p s_{i}<p s i_{-} \text {open }\end{cases}
\end{aligned}
$$

where $T_{\min }$ is daily minimum temperature; $w_{i}$ is the soil water stress of soil layer $i ; p s_{i}$ is soil water potential of soil layer $i$, which is estimated from soil water content based on equations from Saxton and Rawls (2006); $r_{i}$ is the root fractions distributed in soil layer $i$; psi_close and psi_open are the tolerance of soil water potential for stomata overall close and open.

Leaf stomatal resistance and leaf photosynthesis are coupled together through the following equation (Bonan, 1996; Collatz et al., 1991; Sellers et al., 1996).

$$
\frac{1}{r_{s}}=m \frac{A}{c_{s}} \frac{e_{s}}{e_{i}} P_{a t m}+b
$$

where $r_{s}$ is leaf stomatal resistance, $m$ is an empirical parameter, $A$ is leaf photosynthesis, $c_{s}$ is leaf surface $\mathrm{CO}_{2}$ concentration, $e_{s}$ is leaf surface vapor pressure, $e_{i}$ is saturated vapor pressure inside the leaf, $b$ is the minimum stomata conductance with $A=0$. Together with the following equations:

$$
\begin{aligned}
& c_{s}=c_{a}-1.37 r_{b} P_{a t m} A \\
& e_{s}=\frac{e_{a}^{\prime} r_{s}+e_{i} r_{b}}{r_{b}+r_{s}}
\end{aligned}
$$

where $c_{a}$ is the atmospheric $\mathrm{CO}_{2}$ concentration, $\mathrm{r}_{\mathrm{b}}$ is the boundary resistance, $e_{a}$ ' is vapor pressure of air, stomatal resistance is the larger two roots of this quadratic equation (Bonan, 1996)

$$
\left(\frac{m A P_{a t m} e_{a}^{\prime}}{c_{s} e_{i}}+b\right) r_{s}^{2}+\left(\frac{m A P_{a t m} r_{b}}{c_{s}}+b r_{b}-1\right) r_{s}-r_{b}=0
$$

Index $x_{g s}$ : Indication of growing status, which is 0 when the air temperature is less than the minimum photosynthesis temperature (no growth), and 1 when it is otherwise. 


\subsection{Modeling net primary productivity (NPP) in the DLEM}

NPP is the net carbon gain by vegetation and equals the difference between GPP and plant respiration, which is calculated as:

$$
\begin{aligned}
& G r=0.25 \times G P P \\
& N P P=G P P-M r-G r
\end{aligned}
$$

The DLEM estimates maintenance respiration ( $\mathrm{Mr}$, unit: $\mathrm{g} \mathrm{C} \mathrm{m}^{-2} \mathrm{day}^{-1}$ ) and growth respiration ( $G r$, unit: $\mathrm{g} \mathrm{C} \mathrm{m}^{-2}$ day $^{-1}$ ), respectively. $G r$ is calculated by assuming that the fixed part of assimilated $\mathrm{C}$ will be used to construct new tissue (for turnover or plant growth). During these processes, $25 \%$ of the left GPP is supposed to be used as growth respiration (Prince et al., 1995). Maintenance respiration is related to surface temperature and biomass nitrogen content. The following equation is used to calculate the maintenance respiration of leaf, sapwood, fine root, and coarse root:

$$
M r_{i}=r f \times R_{\text {coeff }_{-} i} \times f(T) \times N_{i}
$$

where $i$ denotes the carbon pool of different plants (leaf, sapwood, fine root, or coarse root); $M r_{i}\left(\mathrm{~g} \mathrm{C} \mathrm{m}^{-2} \mathrm{day}^{-1}\right)$ is the maintenance respiration of different pools; $r f$ is a parameter indicating growing phase, which is set at 0.5 for non-growing season and 1.0 for growing season (growing season and non-growing season are defined based on satellite-observed vegetation phenology); $R_{\text {coeff }_{i}}$ is a plant functional type specific respiration coefficient of pool $i ; N_{i}(\mathrm{~g} \mathrm{~N}$ $\mathrm{m}^{-2}$ ) is the nitrogen content of pool $i ; f(T)$ is the temperature factor, calculated as:

$$
f(T)=e^{308.56 \times\left(\frac{1}{56.02}-\frac{1}{T+46.02}\right)}
$$

where $T$ is the daily average air temperature for modeling aboveground carbon pools such as leaf, sapwood, and heartwood or soil temperature for modeling belowground pools such as coarse root and fine root.

\subsection{Input datasets}

The spatially explicit datasets for driving the DLEM model includes time series of daily climate, annual LCLUC, nitrogen deposition, tropospheric ozone, $\mathrm{CO}_{2}$ concentration, and land management practices (irrigation and nitrogen fertilizer use). All data was compiled at a spatial resolution of $0.5^{\circ} \times 0.5^{\circ}$. The daily climate data (including average, maximum, minimum air temperature, precipitation, and shortwave radiation) were from the CRU-NCEP dataset that combines the strengths of the CRU and NCEP/NCAR reanalysis products and provides global gridded and 6-hourly time-varying climatologic product for the period of 1901-2010 (Wei et al., 2013). The contemporary vegetation map includes 19 plant functional types (Figure 1). The transient vegetation map was created by integrating multiple land cover maps including Landsat imageries, the National Land Cover Dataset 2000 (www.usgs. gov) and the global database of lakes, reservoirs, and wetlands. When a land conversion occurs, such as forest conversion to cropland, a new cohort is formed and the disturbed land area within the grid cell is then proportionally subtracted from the undisturbed potential vegetation. Four types of natural vegetation distribution at the grid cell level were generated based on SYNMAP land cover products (Jung et al., 2006). The cropland and urban distribution data during 1901-2005 were developed by aggregating the 5-arc minute resolution HYDE v3.1 global cropland distribution data (Klein Goldewijk et al., 
2011). The gridded monthly $\mathrm{CO}_{2}$ concentration from 1901-2010 were derived from Multi-scale Synthesis and Terrestrial Model Intercomparison Project (MSTIMP). Other datasets included nitrogen deposition (Dentener, 2006), tropospheric ozone (Felzer et al., 2004) and nitrogen fertilization (Food and Agriculture organization of the United Nations (FAO); http://faostat.fao.org).

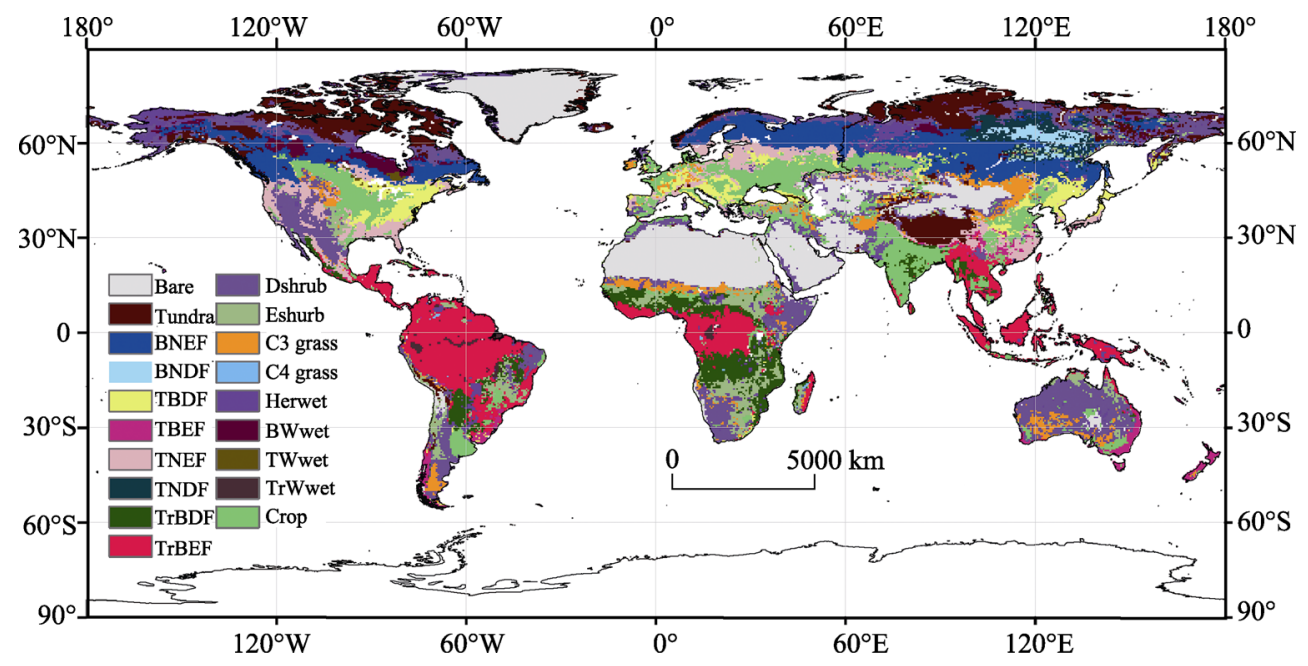

Figure 1 Global contemporary vegetation map used by the Dynamic Land Ecosystem Model (DLEM) in year 2005. BNEF: Boreal Needleleaf Evergreen Forest, BNDF: Boreal Needleleaf Deciduous Forest, TBDF: Temperate Broadleaf Deciduous Forest, TBEF: Temperate Broadleaf Evergreen Forest, TNEF: Temperate Needleleaf Evergreen Forest, TNDF: Temperate Needleleaf Deciduous Forest, TrBDF: Tropical Broadleaf Deciduous Forest, TrBEF: Tropical Broadleaf Evergreen Forest, Dshrub: Deciduous Shrubland, Eshrub: Evergreen Shrubland, Herwet: Herbaceous Wetland, BWwet: Boreal Woody Wetland, TWwet: Temperate Woody Wetland, TrWwet: Tropical Woody Wetland.

\subsection{Model simulation and implementation}

The model simulates the instantaneous exchange of carbon, nitrogen and water cycles following three important stages: an equilibrium stage, a 3000-year spin-up stage, and a transient stage. The simulation starts with an equilibrium run with 30-year (1901-1930) average climate data, while the atmospheric $\mathrm{CO}_{2}$ concentration, tropospheric ozone, nitrogen deposition, and land use and land cover patterns are kept at the 1900 level, to develop the simulation baseline for carbon, nitrogen, and water pools. The equilibrium is assumed to occur when the net carbon exchange between the atmosphere and terrestrial ecosystem is less than $0.1 \mathrm{~g} \mathrm{C} \mathrm{m}^{-2}$, the change in soil water pool in less than $0.1 \mathrm{~mm}$, and the difference in the soil mineral nitrogen content and nitrogen uptake less than $0.1 \mathrm{~g} \mathrm{~N} \mathrm{~m}^{-2}$ among consecutive years. After the equilibrium run, a 3000-year spin up is carried out using random series of detrended climate data and land-use land-cover distribution in 1900 to reduce system fluctuations caused by simulation mode shifting from equilibrium to transient mode. The transient simulation driven by changes in climate, atmospheric chemistry (nitrogen deposition, tropospheric ozone, and increasing atmospheric $\mathrm{CO}_{2}$ concentration), and land-use and land-cover. For this study, we started our simulation from 1900 to capture the legacy effects of environmental changes. However, our analysis was focused on the terrestrial NPP for the first decade of the 21st century (2000-2009). 


\subsection{Model evaluation}

We evaluated the DLEM performance at the site and global level by comparing simulated carbon fluxes against those from flux tower sites and MODIS, respectively. GPP is an important carbon flux being widely used for calculating NPP. We compared the DLEMsimulated GPP with Eddy Covariance GPP at Harvard Forest, MA, University of Michigan Biological Station (UMBS), MI and Mead Rainfed, NE (Figure 2). Harvard Forest and UMBS consists of deciduous broadleaf forest, while Mead Rainfed is a cropland site. Our results show that DLEM can well capture the seasonality of GPP when compared to EC estimates.

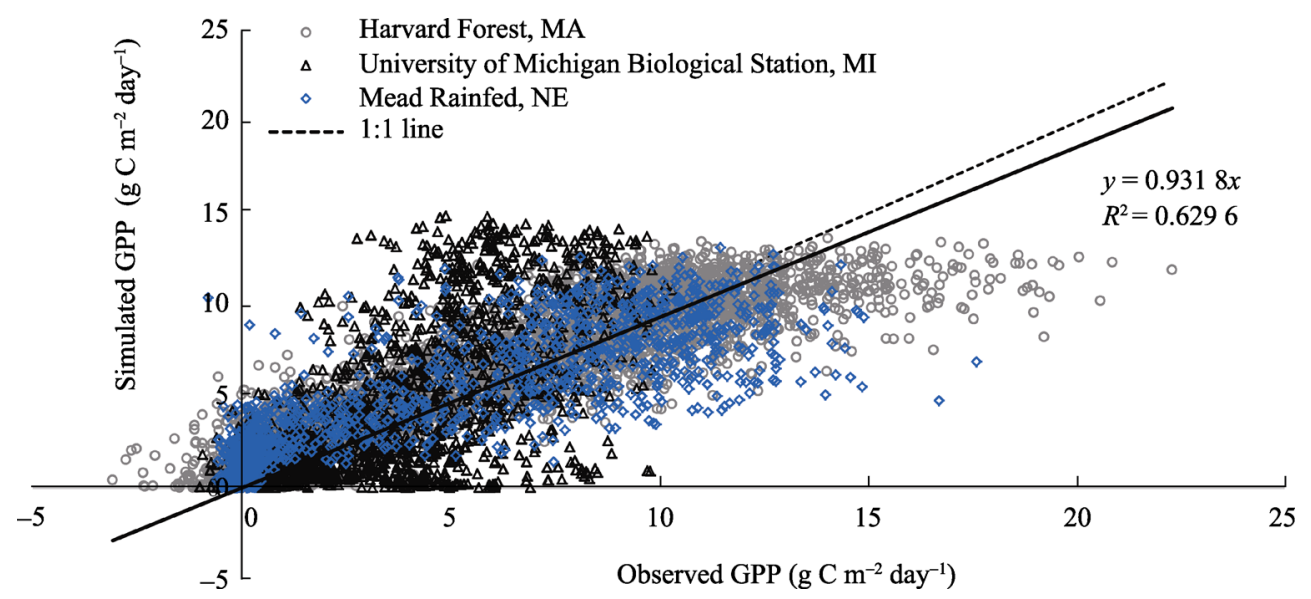

Figure 2 Comparisons of DLEM-simulated (black line) and Eddy Covariance measured (grey line) daily GPP at three selected sites: Harvard Forest, MA, University of Michigan Biological Station, MI, and Mead Rainfed, NE

We further evaluated DLEM NPP at the global scale by comparing it with the MODIS NPP product. The spatial pattern of the DLEM-simulated NPP is consistent with that of the MODIS-derived NPP, with large spatial variation across the globe (Pan et al., 2014b). Terrestrial NPP in low-latitude regions is the highest compared to mid- and high-latitude regions, indicating the dominant role of temperature and moisture availability in determining the terrestrial NPP. We further compared the DLEM-simulated NPP vs. MODIS NPP for all grids during 2000-2009 (Figure 3). Since MODIS estimates are not available for bare land such as northern Africa, western China and southern Mongolia, we excluded those areas from the comparison. DLEM-simulated NPP for all grids are in good agreement with the MODIS NPP product $\left(R^{2}=0.62\right)$.

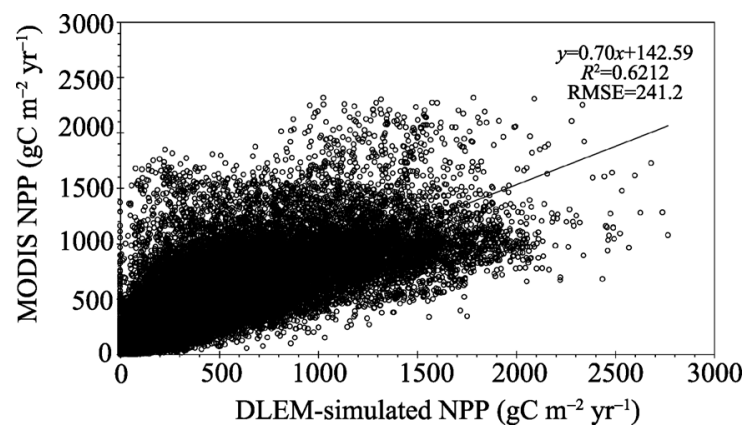

Figure 3 Comparison of the DLEM-simulated NPP with MODIS-NPP for all grids of the global terrestrial ecosystem during 2000-2009 


\section{Results}

\subsection{Inter-annual variation in the global terrestrial NPP}

Over the period 2000-2009, global NPP ranged from 52.8 to $56.4 \mathrm{Pg} \mathrm{C}$ $\mathrm{yr}^{-1}$. The DLEM-simulations show substantial year-to-year variations in global terrestrial NPP for the contemporary period (Figure 4). Inter-annual variation in global NPP was tightly coupled with precipitation variability during the study period. Compared to the decadal mean, global NPP declined in low precipitation years of 2001, 2002, 2003 and 2005. However, higher than average (2000-2009) precipitation resulted in an increase in global NPP in 2006, 2007 and 2008. In 2000, although precipitation was higher than average, below-average temperatures may be a possible reason for the decline in terrestrial NPP indicating that temperature constraints may limit primary productivity. Increasing temperature had a negative effect on global NPP, while precipitation was positively correlated with global NPP. Precipitation explained $63 \%(P<0.05)$ of the variation in terrestrial NPP, while the rest was attributed to changes in temperature and other environmental
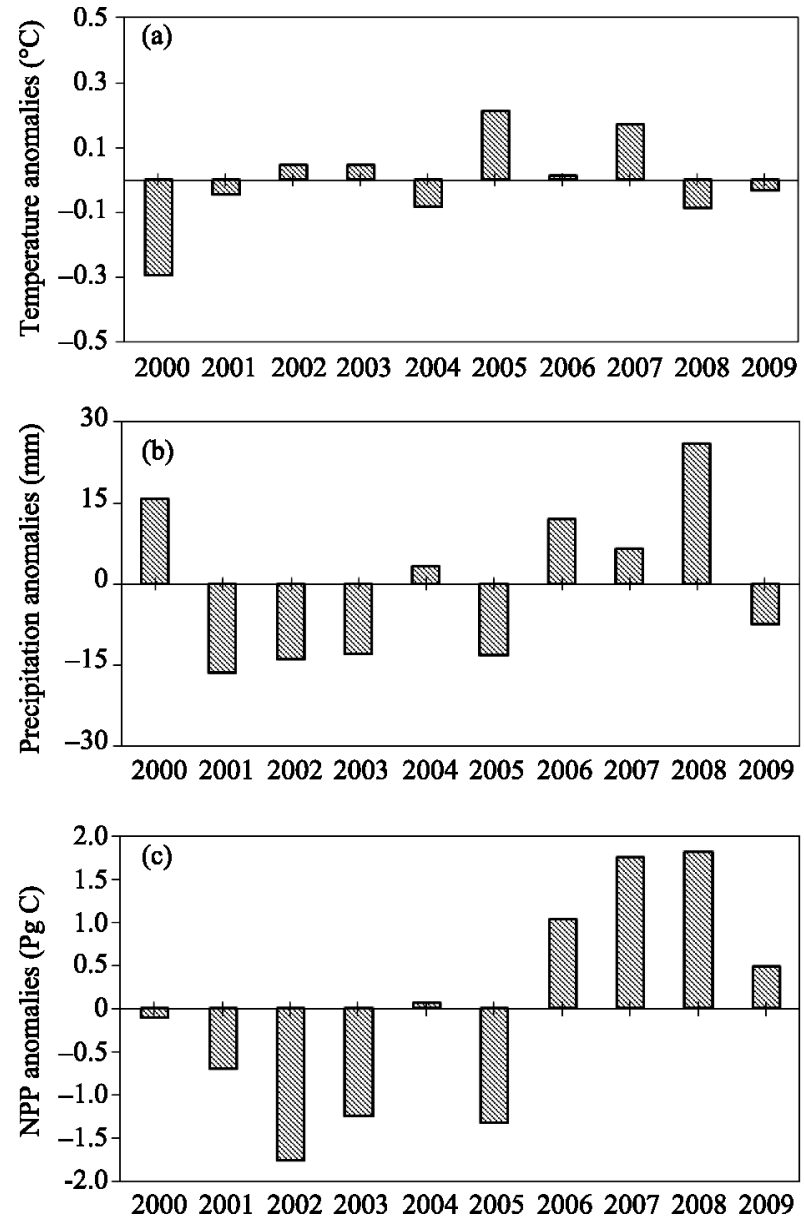

Figure 4 Effect of inter-annual variation in precipitation and temperature on global NPP during the contemporary period (2000-2009): temperature anomalies (a), precipitation anomalies (b) and NPP anomalies (c) factors.

\subsection{Decadal means and changes in NPP during wet and dry years}

The DLEM-simulations show that, for the contemporary period (2000-2009), the combination of climate variability, increasing atmospheric $\mathrm{CO}_{2}$, nitrogen deposition, tropospheric ozone concentration, and land-use land-cover change resulted in a global average terrestrial NPP of about $54.57 \mathrm{Pg} \mathrm{C} \mathrm{yr}^{-1}$. In a specific year, wet or dry climatic conditions resulted in large changes in the magnitude of global terrestrial NPP. The global terrestrial NPP during the dry year of 2002 and the wet year of 2008 was $52.81 \mathrm{Pg} \mathrm{C} \mathrm{yr}^{-1}$ and $56.39 \mathrm{Pg} \mathrm{C} \mathrm{yr}^{-1}$, respectively, which resulted in a change in magnitude of $3.58 \mathrm{Pg} \mathrm{C} \mathrm{yr}^{-1}$ between wet and dry years. The difference between the decadal mean and the dry (2002) or wet (2008) year shows 
that tropical region experienced the largest variation in terrestrial NPP due to wet or dry climatic conditions (Figure 5). In wet years, a larger increase in terrestrial NPP was prevalent in Amazonia, Africa and Australia. However, in dry years, we found a decline in terrestrial NPP by $3.2 \%$ compared to the decadal mean, primarily due to limited moisture supply in tropical regions.

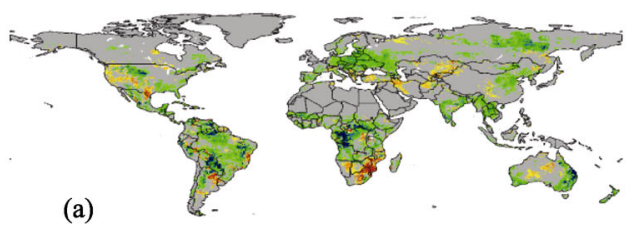

(a)

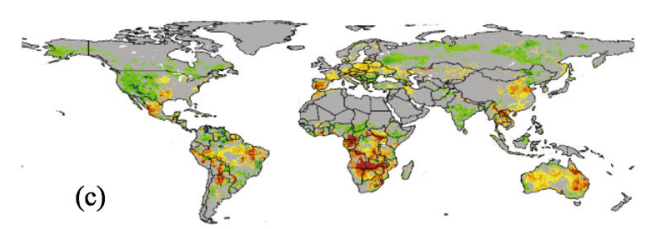

$\mathrm{NPP}\left(\mathrm{g} \mathrm{C} \mathrm{m}^{-2} \mathrm{yr}^{-1}\right)$

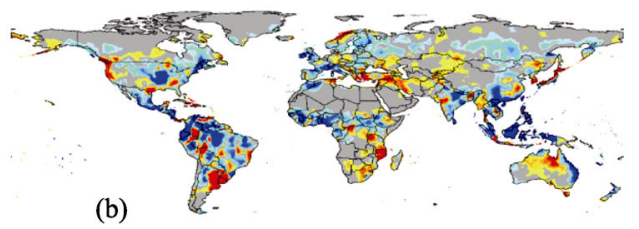

(b)

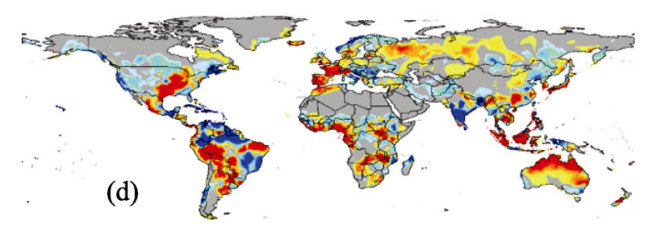

$\operatorname{Prec}\left(\mathrm{mm} \mathrm{yr}^{-1}\right)$
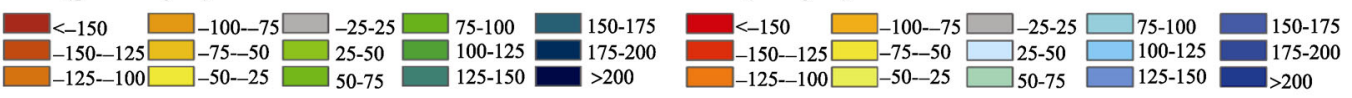

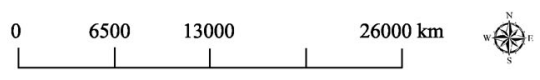

Figure 5 Changes in terrestrial NPP during wet and dry years calculated as a difference between wet or dry years and decadal mean: (a) the difference between wet year (2008) and decadal mean NPP (wet year NPP - decadal NPP), (b) the difference between wet year (2008) and decadal mean precipitation, (c) dry year (2002) and decadal mean NPP (dry year NPP - decadal NPP), and (d) dry year (2002) and decadal mean precipitation

\subsection{Changes in the latitudinal terrestrial NPP during 2000-2009}

Our results show large year-to-year variations in terrestrial NPP with large differences in the magnitude of decadal NPP across latitudes. The amplitude of terrestrial NPP calculated as the difference between maximum and minimum NPP during 2000-2009 was the highest in low-latitude regions $(2.85 \mathrm{Pg} \mathrm{C})$, while the lowest appeared in high-latitude regions $(0.29$ $\mathrm{Pg} \mathrm{C}$ ). Low-latitude regions experienced the largest variation (34.5-37.4 Pg C) in terrestrial NPP with higher than decadal average (2000-2009) NPP in high precipitation years of 2006, 2007, and 2008. However, mid- and high-latitude regions show the smallest variations in terrestrial NPP between years with higher fluctuations occurring in mid-latitude regions (15.5-16.9 Pg C) compared to high-latitude regions (2.2-2.5 Pg C) (Figure 6).

In low-latitude regions $\left(30^{\circ} \mathrm{S}-30^{\circ} \mathrm{N}\right)$, the DLEM estimated a terrestrial NPP of $36.1 \mathrm{Pg} \mathrm{C}$ $\mathrm{yr}^{-1}$ for the contemporary period (2000-2009), accounting for $66.3 \%$ of global total. Comparisons of terrestrial NPP along low latitudes with specific climatic factors (temperature and precipitation) indicate that productive regions with high terrestrial NPP are those that often receive a high amount of precipitation. The temporal patterns of terrestrial NPP show that low-latitude regions experienced a decline in NPP before 2005 compared to the decadal mean, but then NPP started to increase afterwards primarily due to higher than average (2000-2009) precipitation (Figure 6). In low-latitude regions, precipitation was positively 

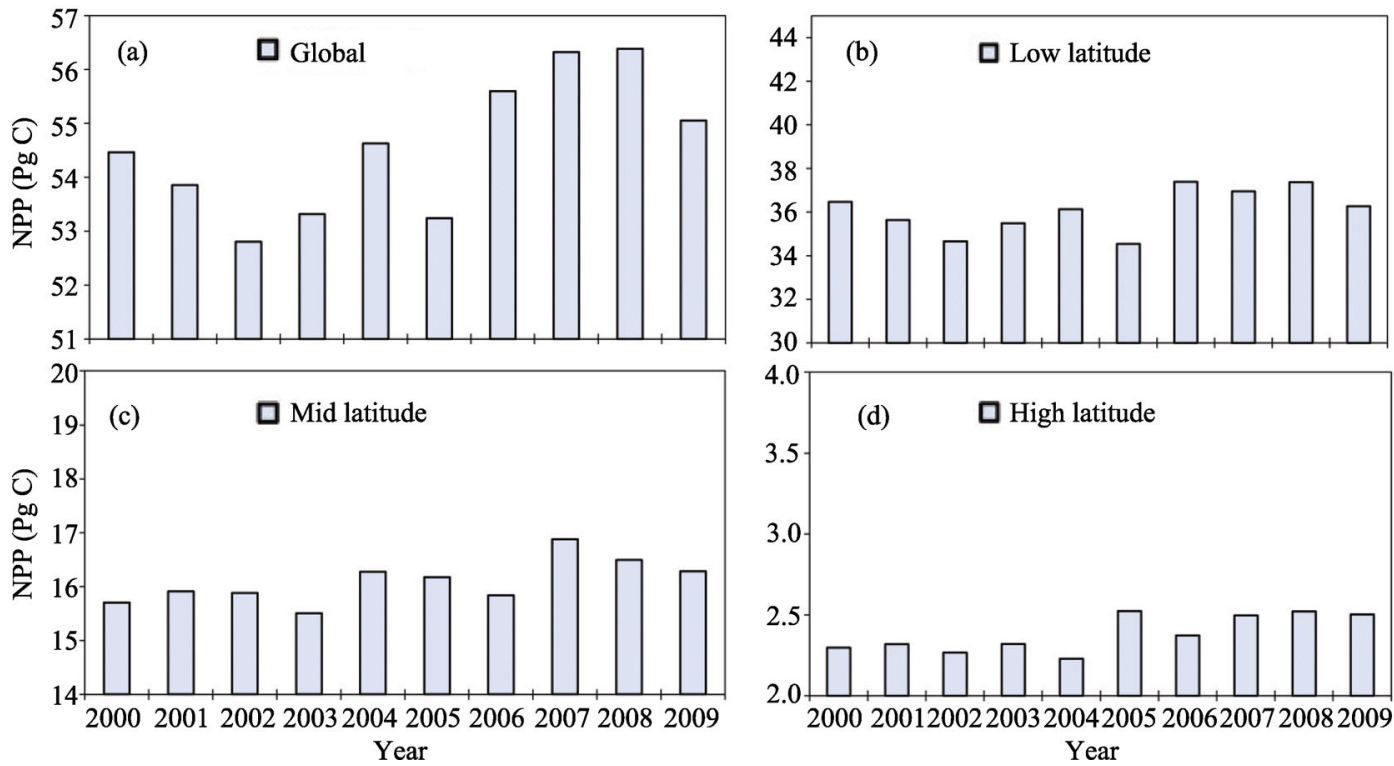

Figure 6 Magnitude and inter-annual variation in terrestrial NPP at the global and latitudinal scales. The scales for $y$-axis are different for low-, mid- and high-latitude regions and the globe
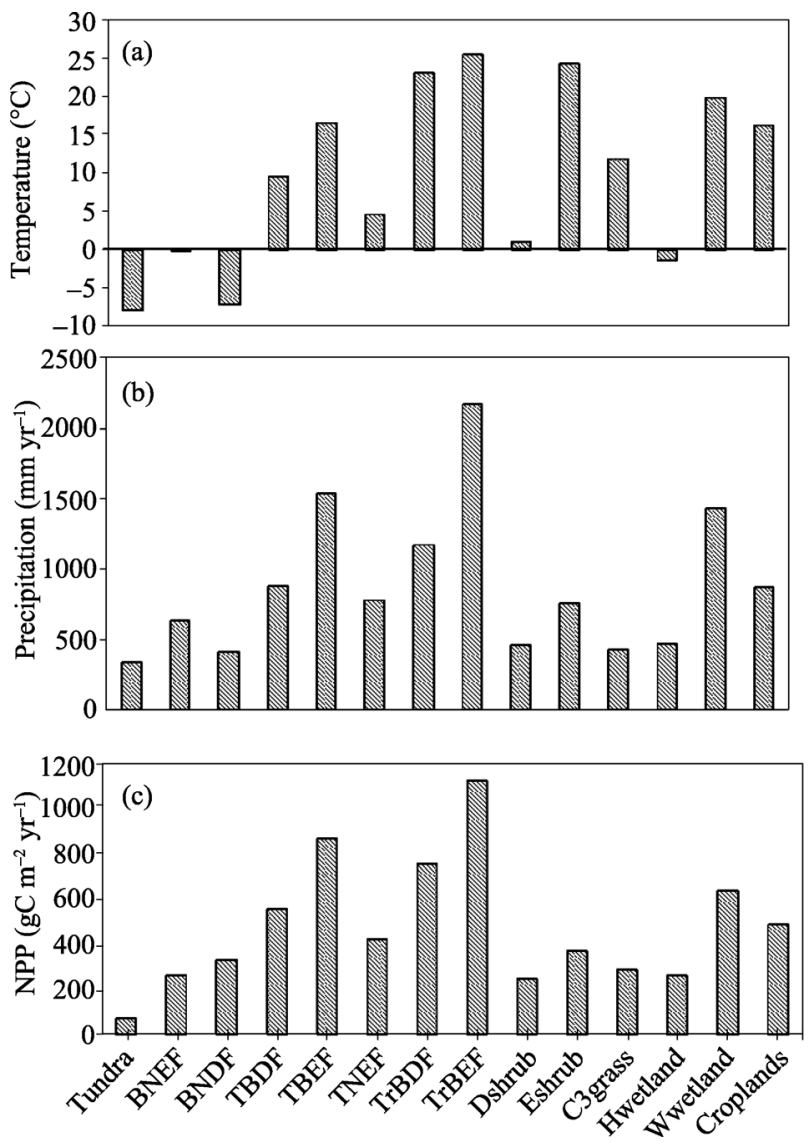

Figure 7 Biome level mean NPP as estimated by the Dynamic Land Ecosystem Model (DLEM) during 2000-2009 correlated with terrestrial NPP explaining $65 \%(\mathrm{P}-$ value $<0.05)$ of the variation. Temperature, however, was negatively correlated with NPP explaining $28 \%$ of the variation in NPP, although the effect was not statistically significant $(\mathrm{P}$-value $=$ 0.12).

Along the mid-latitude $\left(30^{\circ}-60^{\circ} \mathrm{S}\right.$, $30^{\circ}-60^{\circ} \mathrm{N}$ ) regions, the DLEM estimated a terrestrial NPP of $16.1 \mathrm{Pg} \mathrm{C}$ $\mathrm{yr}^{-1}$ for the contemporary period (2000-2009), accounting for $29.5 \%$ of the global total. Higher temperature was often associated with an increase in terrestrial NPP in midlatitude regions with the largest NPP increase occurring in 2007 (4.8\% increase compared to the decadal mean). In mid-latitude regions, temperature explained $24 \%$ of the variation in terrestrial NPP (P-value $=$ 0.15 ); however, precipitation was found to be weakly correlated with NPP explaining only $1.8 \%$ of the variation. 
In high-latitude regions $\left(60^{\circ}-90^{\circ} \mathrm{S}, 60^{\circ}-90^{\circ} \mathrm{N}\right)$, the DLEM simulation estimates a terrestrial NPP of $2.4 \mathrm{Pg} \mathrm{C} \mathrm{yr}^{-1}$ during the contemporary period (2000-2009), accounting for 4.2\% of the global total. Similar to mid-latitudes, higher temperature were often associated with an increase in terrestrial NPP in high-latitude regions with the largest NPP increase occurring in 2007 (5.8\% increase compared to the decadal mean), and temperature explained 28\% of the variation in terrestrial NPP (P-value $=0.10)$, while precipitation was found to be weakly correlated with NPP explaining only $2.4 \%$ of the variation.

\subsection{Changes in terrestrial NPP at the biome level}

The DLEM simulations show substantial variation in terrestrial NPP across major biomes (Figure 7). Biomes that receive high amounts of precipitation associated with higher air temperature show a large increase in NPP compared to biomes receiving low precipitation. The NPP per unit area during 2000-2009 was the highest in tropical forest, temperate forest and woody wetland, while the lowest in boreal forest and tundra. DLEM simulated a highest terrestrial NPP of $1122.4 \mathrm{~g} \mathrm{C} \mathrm{m}^{-2} \mathrm{yr}^{-1}$ for the tropical broadleaf evergreen forest, while the lowest terrestrial NPP was $70.3 \mathrm{~g} \mathrm{C} \mathrm{m}^{-2}$ for tundra vegetation during 2000-2009. We found that the biome-level NPP response was highly variable, with the largest inter-annual variation (measured as the ratio of standard deviation of terrestrial NPP among years to the decadal mean) occurring in boreal needleleaf evergreen forest $(9.35 \%)$ and the least variation occurring in tropical broadleaf deciduous forest (Table 2).

Table 2 Minimum, maximum, decadal mean and coefficient of variation in terrestrial NPP across biomes during 2000-2009

\begin{tabular}{|c|c|c|c|c|}
\hline \multirow{2}{*}{ Biome } & \multicolumn{3}{|c|}{$\mathrm{NPP}\left(\mathrm{g} \mathrm{C} \mathrm{m}^{-2} \mathrm{yr}^{-1}\right)$} & \multirow{2}{*}{ Coefficient of variation $(\%)$} \\
\hline & Min & Mean & Max & \\
\hline Tundra & 68.0 & 70.3 & 73.8 & 2.94 \\
\hline $\mathrm{BNEF}$ & 244.1 & 258.6 & 270.4 & 3.13 \\
\hline BNDF & 290.6 & 324.1 & 374.1 & 9.35 \\
\hline TBDF & 530.4 & 551.6 & 576.0 & 2.52 \\
\hline TBEF & 848.4 & 867.6 & 901.7 & 1.87 \\
\hline TNEF & 399.7 & 418.1 & 443.6 & 3.28 \\
\hline TrBDF & 684.5 & 753.6 & 795.3 & 4.39 \\
\hline TrBEF & 1098.4 & 1122.4 & 1159.4 & 1.71 \\
\hline Dec. Shrub & 237.6 & 245.4 & 254.8 & 2.64 \\
\hline Eve. Shrub & 327.3 & 369.2 & 405.9 & 6.83 \\
\hline Grass & 273.4 & 284.8 & 296.0 & 2.24 \\
\hline Her. Wetland & 249.5 & 261.8 & 275.1 & 3.67 \\
\hline Woody Wetland & 610.1 & 635.9 & 663.2 & 2.91 \\
\hline Cropland & 468.0 & 487.0 & 510.3 & 2.65 \\
\hline
\end{tabular}

BNEF: Boreal Needleaf Evergreen Forest; BNDF: Boreal Needleleaf Deciduous Forest; TBDF: Temperate Broadleaf Deciduous Forest; TBEF: Temperate Broadleaf Evergreen Forest; TNEF: Temperate Needleleaf Evergreen Forest; TrBDF: Tropical Broadleaf Deciduous Forest; TrBEF: Tropical Broadleaf Evergreen Forest. 


\section{Discussion}

\subsection{Comparison of DLEM-simulated terrestrial NPP with other estimates}

The DLEM-simulated global terrestrial NPP is comparable with previous estimates based on remote sensing and ecosystem models. The DLEM-simulated global terrestrial NPP during the period 2000-2009 was 54.57 $\mathrm{Pg} \mathrm{C} \mathrm{yr}^{-1}$, which falls in the range of 44 and $66 \mathrm{Pg} \mathrm{C} \mathrm{yr}^{-1}$ as estimated by 17 terrestrial biosphere models (Cramer et al., 1999). The large variations in global NPP estimates among these 17 models are primarily caused by different model representation of nutrient and water constraints on NPP in various terrestrial ecosystems. For instance, both field- and model-based studies indicated that carbon and nitrogen are closely interacted in many terrestrial ecosystems. Some of these models do not consider carbon-nitrogen interaction, which generally results in an overestimate of global NPP. In addition, moisture in root zone is critically important for plants especially in areas under frequent water stress. The DLEM-simulated terrestrial NPP during 2000-2009 (54.57 $\mathrm{Pg} \mathrm{C} \mathrm{yr}^{-1}$ ) is

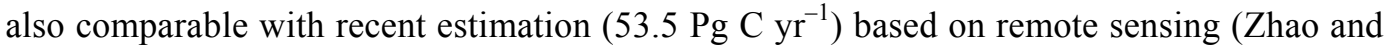
Running, 2010). Our study further indicate an inter-annual variation (measured as a standard deviation among years) of 1.28 Pg C during 2000-2009 which is comparable with inter-annual variation (1.2 Pg C) based on Ahlström et al. (2012).

\subsection{Contemporary patterns of global terrestrial NPP}

Our study suggests that terrestrial NPP is tightly coupled with inter-annual variation in the climate during the contemporary period. Despite a relatively short (10 years) period analysis, a strong correlation was found worldwide, with negative correlation in response to increasing temperatures dominating in the low-latitude regions and positive correlation dominating in the mid- and high-latitude regions. Precipitation, however, had a positive correlation with NPP primarily because precipitation determines the average soil moisture availability in any location, which is critical for plant growth and sustenance. Bastos et al. (2013) found a similar pattern of terrestrial NPP, where changes in terrestrial NPP were highly correlated with prevalent climatic conditions. Our results further indicate that variation in NPP is related to variation in precipitation in the tropics, but is correlated to variation in temperature in the mid- and high-latitude regions. This is because tropics are primarily thought to be moisture limited (Murphy and Lugo, 1986), so high precipitation may favor plant production by reducing moisture stress. Wu et al. (2011) found that experimentally reduced precipitation suppressed above-ground NPP across ecosystems, while increased precipitation stimulated plant growth. In a similar study, Mohamed et al. (2004) reported large NPP reduction in tropical biomes primarily due to greater impacts of drought and weaker physiological adjustment to precipitation variability. Such drought events induced by precipitation deficit and extreme heat have resulted in a net reduction in terrestrial primary production by $30 \%$ across Europe (Ciais et al., 2005).

Our study also indicates that inter-annual climatic variability was the major factor that determined the magnitude and temporal variability in terrestrial NPP during 2000-2009. The mechanism for variability in NPP in the low-latitude regions is attributed to the variation in precipitation (Zeng et al., 2005) and/or increased fire during drought years (van der Werf et al., 2004). However, in mid- and high-latitude regions, inter-annual variation in temperature 
was the major factor that determined the magnitude of NPP. For instance, Nemani et al. (2003) reported that cold winter temperatures and cloudy summers may limit productivity in mid- and high-latitude regions. Therefore, temperature increase may promote plant productivity by alleviating temperature limitations to plant growth and lengthening the growing season in high-latitude ecosystems.

\subsection{Biome-level NPP response to climate change}

Our results indicated that forest has the greatest potential to increase NPP compared to other biomes. Because forest may respond to warmer temperatures and increasing precipitation by enhancing plant production (Lewis, 2006), we found large magnitudes of terrestrial NPP in forest compared to other biomes. Mainly due to warmer temperature and high precipitation, the magnitude of terrestrial NPP was the largest in tropical broadleaf evergreen forest $\left(1122.4 \mathrm{gC} \mathrm{m}^{-2}\right)$, while the largest coefficient of variation (measured as the ratio of standard deviation of NPP among years to decadal mean) among years occurred in boreal needleleaf deciduous forest $(9.35 \%)$. Thus, our results showed that during the contemporary period, tropical forest contributed to $28.2 \%$ of global terrestrial NPP, followed by temperate forest $(27.6 \%)$, wetlands $(13.5 \%)$, shrublands $(9.2 \%)$, and boreal forest $(8.8 \%)$.

\subsection{Uncertainty and future work}

Similar to other modeling studies (Cramer et al., 1999; Melillo et al., 1993; Sitch et al., 2008), there are uncertainties in this study that need to be addressed in future research. Some of these uncertainties are associated with the accuracy of model driving forces and model parameters. Furthermore, acclimation is an important mechanism by which the terrestrial ecosystem may cope with elevated temperatures and other environmental stresses (Oechel et $a l ., 2000)$. The effects of changes in temperature and precipitation may be over-estimated if we take plant acclimation into account. In addition, this study examined the effect of climate change on global terrestrial NPP based on an all-factor combined experiment. Thus, NPP response to climate change as examined in this study might be the result of interaction with other environmental factors (elevated $\mathrm{CO}_{2}$, nitrogen deposition etc.) and anthropogenic factors such as land use changes (Tian et al., 2012). Future research is required to separate the effect of climate change and other environmental factors on terrestrial NPP using a full factorial design.

\section{Acknowledgements}

This research has been supported by NSF Decadal and Regional Climate Prediction using Earth System Models (AGS-1243220, NSF Dynamics of Coupled Natural and Human Systems (1210360), NSF Computer and Network Systems (CNS-1059376), NASA Land Cover/Land Use Change Program (NNX08AL73G S01), and NASA Interdisciplinary Science Program (NNX10AU06G, NNX11AD47G).

\section{References}

Ahlström A, Miller P A, Smith B, 2012. Too early to infer a global NPP decline since 2000. Geophysical Research 
Letters, 39(15). doi: 10.1029/2012GL052336.

Beer C, Reichstein M, Tomelleri E et al., 2010. Terrestrial gross carbon dioxide uptake: Global distribution and covariation with climate. Science, 329(5993): 834-838. doi: 10.1126/science.1184984.

Bonan G B, 1996. Land surface model (LSM version 1.0) for ecological, hydrological, and atmospheric studies: Technical description and users guide. Technical note: National Center for Atmospheric Research, Boulder, CO (United States). Climate and Global Dynamics Div.

Chen G, Tian H, Zhang C et al., 2012. Drought in the Southern United States over the 20th century: Variability and its impacts on terrestrial ecosystem productivity and carbon storage. Climatic Change, 114(2): 379-397. doi: 10.1007/s10584-012-0410.

Ciais P, Reichstein M, Viovy N et al., 2005. Europe-wide reduction in primary productivity caused by the heat and drought in 2003. Nature, 437(7058): 529-533. doi: 10.1038/nature03972.

Collatz G J, Ball J T, Grivet C et al., 1991. Physiological and environmental regulation of stomatal conductance, photosynthesis and transpiration: A model that includes a laminar boundary layer. Agricultural and Forest Meteorology, 54(2): 107-136. doi: 10.1016/0168-1923(91)90002-8.

Costanza R, d'Arge R, Groot R D et al., 1998. The value of the world's ecosystem services and natural capital. Ecological Economics, 25: 3-15.

Cramer W, Kicklighter D, Bondeau A et al., 1999. Comparing global models of terrestrial net primary productivity (NPP): Overview and key results. Global Change Biology, 5(S1): 1-15. doi: 10.1046/j.1365-2486. 1999.00009.x.

Dentener F, 2006. Global maps of atmospheric nitrogen deposition, 1860, 1993, and 2050. Data set. Available on-line (http://daac. ornl. gov/) from Oak Ridge National Laboratory Distributed Active Archive Center, Oak Ridge, TN, USA.

Dermody O, 2006. Mucking through multifactor experiments: Design and analysis of multifactor studies in global change research. New Phytologist, 172(4): 598-600. doi: 10.1111/j.1469-8137.2006.01921.x.

Farquhar G, von Caemmerer S V, Berry J, 1980. A biochemical model of photosynthetic $\mathrm{CO}_{2}$ assimilation in leaves of C3 species. Planta, 149(1): 78-90. doi: 10.1007/BF00386231.

Felzer B, Kicklighter D, Melillo J et al., 2004. Effects of ozone on net primary production and carbon sequestration in the conterminous United States using a biogeochemistry model. Tellus B, 56(3): 230-248. doi: 10.1111/j.1600-0889.2004.00097.x.

Huntzinger D, Post W M, Wei Y et al., 2012. North American Carbon Program (NACP) regional interim synthesis: Terrestrial biospheric model intercomparison. Ecological Modelling, 232: 144-157. doi: 10.1016 j.ecolmodel. 2012.02.004.

Jung M, Henkel K, Herold M et al., 2006. Exploiting synergies of global land cover products for carbon cycle modeling. Remote Sensing of Environment, 101(4): 534-553. doi: 10.1016/j.rse.2006.01.020.

Klein Goldewijk K, Beusen A, Van Drecht G et al., 2011. The HYDE 3.1 spatially explicit database of human-induced global land-use change over the past 12,000 years. Global Ecology and Biogeography, 20(1): 73-86. doi: 10.1111/j.1466-8238.2010.00587.x.

Lewis S L, 2006. Tropical forests and the changing earth system. Philosophical Transactions of the Royal Society B: Biological Sciences, 361(1465): 195-210. doi: 10.1098/rstb.2005.1711.

Liu M, Tian H, Yang Q et al., 2013. Long-term trends in evapotranspiration and runoff over the drainage basins of the Gulf of Mexico during 1901-2008. Water Resources Research, 49(4): 1988-2012. doi: 10.1002/ wrcr.20180.

Lu C, Tian H, 2013. Net greenhouse gas balance in response to nitrogen enrichment: Perspectives from a coupled biogeochemical model. Global Change Biology, 19(2): 571-588. doi: 10.1111/gcb.12049.

Lu C, Tian H, Liu M et al., 2012. Effect of nitrogen deposition on China's terrestrial carbon uptake in the context of multifactor environmental changes. Ecological Applications, 22(1): 53-75. doi: 10.1890/10-1685.1.

Melillo J M, McGuire A D, Kicklighter D W et al., 1993. Global climate change and terrestrial net primary production. Nature, 363(6426): 234-240. doi: 10.1016/j.scitotenv.2004.03.009.

Mohamed M, Babiker I S, Chen Z et al., 2004. The role of climate variability in the inter-annual variation of ter- 
restrial net primary production (NPP). Science of the Total Environment, 332(1): 123-137.

Murphy P G, Lugo A E, 1986. Ecology of tropical dry forest. Annual Review of Ecology and Systematics, 67-88. doi: 10.1146/annurev.es.17.110186.000435.

Nemani R R, Keeling C D, Hashimoto H et al. (2003). Climate-driven increases in global terrestrial net primary production from 1982 to 1999 . Science, 300(5625): 1560-1563. doi: 10.1126/science.1082750.

Norby R J, Luo Y, 2004. Evaluating ecosystem responses to rising atmospheric $\mathrm{CO}_{2}$ and global warming in a multi-factor world. New Phytologist, 162(2): 281-293. doi: 10.1111/j.1469-8137.2004.01047.x.

Oechel W C, Vourlitis G L, Hastings S J et al., 2000. Acclimation of ecosystem $\mathrm{CO}_{2}$ exchange in the Alaskan Arctic in response to decadal climate warming. Nature, 406(6799): 978-981. doi: 10.1038/35023137.

Pan S, Tian H, Dangal S R et al., 2014a. Complex spatiotemporal responses of global terrestrial primary production to climate change and increasing atmospheric $\mathrm{CO}_{2}$ in the 21 st century. PloS One, 9, e112810, doi: 10.1371/journal.pone.0112810.

Pan S, Tian H, Dangal S R et al., 2014b. Modeling and monitoring terrestrial primary production in a changing global environment: Toward a multiscale synthesis of observation and simulation. Advances in Meteorology, 17. doi: $10.1155 / 2014 / 965936$.

Piacentini M, Rosina K, 2012. Measuring the Environmental Performance of Metropolitan Areas with Geographic Information Sources. OECD Publishing.

Potter C S, Klooster S, Genovese V, 2012. Net primary production of terrestrial ecosystems from 2000 to 2009. Climatic Change, 115(2): 365-378. doi: 10.1007/s10584-012-0460-2.

Raupach M, Canadell J, Quéré C L, 2008. Anthropogenic and biophysical contributions to increasing atmospheric $\mathrm{CO}_{2}$ growth rate and airborne fraction. Biogeosciences, 5(6): 1601-1613. doi: 10.5194/bg-5-1601-2008.

Ren W, Tian H, Liu M et al., 2007. Effects of tropospheric ozone pollution on net primary productivity and carbon storage in terrestrial ecosystems of China. Journal of Geophysical Research: Atmospheres (1984-2012): 112(D22). doi: 10.1029/2007JD008521.

Ren W, Tian H, Tao B et al., 2011. Impacts of tropospheric ozone and climate change on net primary productivity and net carbon exchange of China's forest ecosystems. Global Ecology and Biogeography, 20(3): 391-406. doi: 10.1111/j.1466-8238.2010.00606.x.

Ruimy A, Dedieu G, Saugier B, 1996. TURC: A diagnostic model of continental gross primary productivity and net primary productivity. Global Biogeochemical Cycles, 10(2): 269-285. doi: 10.1029/96GB00349.

Running S W, Nemani R R, Heinsch F A et al., 2004. A continuous satellite-derived measure of global terrestrial primary production. Bioscience, 54(6): 547-560. doi: 10.1641/0006-3568.

Saxton K, Rawls W, 2006. Soil water characteristic estimates by texture and organic matter for hydrologic solutions. Soil Science Society of America Journal, 70(5): 1569-1578. doi: 10.2136/sssaj2005.0117.

Sellers P, Randall D, Collatz G et al., 1996. A revised land surface parameterization (SiB2) for atmospheric GCMs. Part I: Model formulation. Journal of Climate, 9(4): 676-705. doi: 10.1175/1520-0442(1996)009< 0676:ARLSPF>2.0.CO;2.

Sitch S, Huntingford C, Gedney N et al., 2008. Evaluation of the terrestrial carbon cycle, future plant geography and climate-carbon cycle feedbacks using five Dynamic Global Vegetation Models (DGVMs). Global Change Biology, 14(9): 2015-2039. doi: 10.1111/j.1365-2486.2008.01626.x.

Sitch S, Smith B, Prentice I C et al., 2003. Evaluation of ecosystem dynamics, plant geography and terrestrial carbon cycling in the LPJ dynamic global vegetation model. Global Change Biology, 9(2): 161-185. doi: 10.1046/j.1365-2486.2003.00569.x.

Song X, Tian H, Xu X et al., 2013. Projecting terrestrial carbon sequestration of the southeastern United States in the 21 st century. Ecosphere, 4(7): art88. doi: 10.1890/ES12-00398.1.

Tian H, Chen G, Liu M et al., 2010a. Model estimates of net primary productivity, evapotranspiration, and water use efficiency in the terrestrial ecosystems of the southern United States during 1895-2007. Forest Ecology and Management, 259(7): 1311-1327. doi: 10.1016/j.foreco.2009.10.009.

Tian H, Chen G, Zhang C et al., 2012. Century-scale responses of ecosystem carbon storage and flux to multiple environmental changes in the southern United States. Ecosystems, 15(4): 674-694. doi: 10.1007/s10021-012- 
9539-x.

Tian H, Hall C A, Qi Y, 1998. Modeling primary productivity of the terrestrial biosphere in changing environments: Toward a dynamic biosphere model. Critical Reviews in Plant Sciences, 17(5): 541-557.

Tian H, Liu M, Zhang C et al., 2010b. The dynamic land ecosystem model (DLEM) for simulating terrestrial processes and interactions in the context of multifactor global change. Acta Geographica Sinica, 65(9): 1027-1047. (in Chinese)

Tian H, Melillo J, Kicklighter D et al., 2000. Climatic and biotic controls on annual carbon storage in Amazonian ecosystems. Global Ecology and Biogeography, 9(4): 315-335. doi: 10.1046/j.1365-2699.2000.00198.x.

Tian H, Melillo J, Lu C et al., 2011. China's terrestrial carbon balance: Contributions from multiple global change factors. Global Biogeochemical Cycles, 25(1). doi: 10.1029/2010GB003838.

Tian H, Xu X, Liu M et al., 2010c. Spatial and temporal patterns of $\mathrm{CH}_{4}$ and $\mathrm{N}_{2} \mathrm{O}$ fluxes in terrestrial ecosystems of North America during 1979-2008: application of a global biogeochemistry model. Biogeosciences, 7(9): 2673-2694. doi: 10.5194/bg-7-2673-2010.

Van der Werf G R, Randerson J T, Collatz G J et al., 2004. Continental-scale partitioning of fire emissions during the 1997 to 2001 El Nino/La Nina period. Science, 303(5654): 73-76. doi: 10.1126/science.1090753.

Wang W, Dungan J, Hashimoto $\mathrm{H}$ et al., 2011. Diagnosing and assessing uncertainties of terrestrial ecosystem models in a multimodel ensemble experiment: 1. Primary production. Global Change Biology, 17(3): 13501366. doi: 10.1111/j.1365-2486.2010.02309.x.

Wei Y, Liu S, Huntzinger D et al., 2013. The North American Carbon Program Multi-scale Synthesis and Terrestrial Model Intercomparison Project-Part 2: Environmental driver data. Geoscientific Model Development Discussions, 6(4): 5375-5422. doi: 10.5194/gmdd-6-5375-2013.

Wu Z, Dijkstra P, Koch G W et al., 2011. Responses of terrestrial ecosystems to temperature and precipitation change: A meta-analysis of experimental manipulation. Global Change Biology, 17(2): 927-942. doi: 10.1111/j.1365-2486.2010.02302.x.

$\mathrm{Xu}$ X, Tian H, Zhang C et al., 2010. Attribution of spatial and temporal variations in terrestrial methane flux over North America. Biogeosciences Discussions, 7(4): 5383-5428. doi: 10.5194/bgd-7-5383-2010.

Zeng N, Mariotti A, Wetzel P, 2005. Terrestrial mechanisms of interannual $\mathrm{CO}_{2}$ variability. Global Biogeochemical Cycles, 19(1): doi: 10.1029/2004GB002273.

Zhang C, Tian H, Chappelka A H et al., 2007. Impacts of climatic and atmospheric changes on carbon dynamics in the Great Smoky Mountains National Park. Environmental Pollution, 149(3): 336-347. doi: 10.1016/ j.envpol.2007.05.028.

Zhang C, Tian H, Chen G et al., 2012. Impacts of urbanization on carbon balance in terrestrial ecosystems of the Southern United States. Environmental Pollution, 164: 89-101. doi: 10.1016/j.envpol.2012.01.020.

Zhang C, Tian H, Wang Y et al., 2010. Predicting response of fuel load to future changes in climate and atmospheric composition in the Southern United States. Forest Ecology and Management, 260(4): 556-564. doi: 10.1016/j.foreco.2010.05.012.

Zhao M, Running S W, 2010. Drought-induced reduction in global terrestrial net primary production from 2000 through 2009. Science, 329(5994): 940-943. doi: 10.1126/science.1192666.

Zscheischler J, Michalak A M, Schwalm C et al., 2014. Impact of large-scale climate extremes on biospheric carbon fluxes: An intercomparison based on MsTMIP data. Global Biogeochemical Cycles, 28(6): 585-600. 